\title{
Associations among Procedural Fairness, Tax Compliance, and Tax Re-audits
}

\author{
Ho-Sung KIM'1, Hyun-Ah LEE ${ }^{2}$
}

Received: March 09, 2020 Revised: May 10, 2020 Accepted: June 07, 2020

\begin{abstract}
This study investigates the determinants of the likelihood of a tax re-audit in Korea. It adopts a researcher-administered questionnaire survey method for data collection. The survey questionnaire is randomly distributed to 1,120 individuals with tax-related knowledge and experience. Using a final sample of 342 responses, we conduct a cross-sectional regression analysis to test our hypotheses. The results show that the level of tax non-compliance significantly affects the likelihood of a tax re-audit. This finding suggests that the increase in re-audits in Korea is attributable to the tendency of the tax authority to conduct a re-audit to detect taxpayers' non-compliance behavior by excessively broadening the scope of re-audits. This study also finds that the level of tax non-compliance is influenced by the perception of procedural unfairness, measured by operational inconsistency and regulatory lack of clarity. Lastly, the results reveal that the level of tax non-compliance mediates the relationship between the perception of procedural unfairness and likelihood of a tax re-audit. This finding indicates that enhancing procedural fairness could fundamentally reduce unnecessary re-audits that infringe on the rights of taxpayers, as the likelihood of a tax re-audit is not solely determined by the level of tax non-compliance but also by perceived procedural fairness.
\end{abstract}

Keywords : Tax Re-audit, Tax Compliance, Procedural Fairness, Tax Enforcement, Factor Analysis

JEL Classification Code : H26, K34, K42

\section{Introduction}

In most countries, taxes are an essential source of revenue for the government and are closely correlated with public spending, which contributes to economic growth. Therefore, tax non-compliance behavior that impedes revenue collection has long been an area of concern for the government and tax authority (Long \& Swingen, 1991; Sapiei, Kasipillai, \& Eze, 2014; Nguyen, 2019; Nguyen, Pham, Le, Truong \& Tran, 2020). Tax audits are considered to be an effective policy for improving tax compliance by detecting taxpayers who do not comply with tax laws and regulations (Slemrod, Blumenthal, \& Christian, 2001).

${ }^{1}$ First Author. Tax Accountant, Ph.D. in Business Administration, School of Business, Gachon University. Republic of Korea. Email: tax003@naver.com

${ }^{2}$ Corresponding Author. Associate Professor, School of Business, Gachon University, Korea [Postal Address: 1342 Seongnamdaero, Sujeong-Gu, Seongnam-Si, Gyeonggi-Do, 13120, Korea] Email: halee@gachon.ac.kr; nega1116@naver.com

(c) Copyright: The Author(s)

This is an Open Access article distributed under the terms of the Creative Commons Attribution Non-Commercial License (http://Creativecommons.org/licenses/by-nc/4.0/) which permits unrestricted noncommercial use, distribution, and reproduction in any medium, provided the original work is properly cited.
However, if the tax authority conducts audits without fair procedures, it undermines taxpayers' trust in the authority and thus increases tax non-compliance behavior (Frey, 2003; Hartner, Rechberger, Kirchler, \& Schabmann, 2008; Murphy \& Tyler, 2008). More importantly, in accordance with the rules of double jeopardy, the tax authority is strictly prohibited from re-examining taxpayers' records that have previously been audited (referred to as "tax re-audits" hereafter) except for the limited cases described in the laws. However, approximately 125 legal complaints related to tax re-audits were made during 2006-2017 in Korea and the number continues to rise (Kim, Hur, \& Park, 2017). This increase in tax re-audits has led to growing legal disputes between tax authorities and taxpayers along with concerns over the infringement of taxpayers' rights.

Against this background, this study examines the determinants of the likelihood of a tax re-audit by investigating the mediating effect of tax non-compliance on the relationship between the perception of procedural unfairness and such a likelihood. We first investigate whether the level of tax non-compliance affects the likelihood of a tax re-audit. We assume that the increase in re-audits in Korea is attributable to the tendency of the tax authority to conduct a re-audit to detect taxpayers' non- 
compliance behavior by excessively broadening the scope of re-audits (Kim, 2016; Kim, Hur, \& Park, 2017). Thus, we anticipate that the tax authority is more likely to conduct re-audits when taxpayers tend to be less compliant with tax laws. We, then, investigate whether the level of tax noncompliance is influenced by the perception of procedural unfairness. In the tax literature, procedural fairness refers to whether fair procedures and services are executed by the tax authority (Murphy, 2009; Van Dijke \& Verboon, 2010). Taxpayers become less compliant when they perceive that the tax authority executes unfair procedures or treats them in a disrespectful manner (Hartner, Rechberger, Kirchler, \& Schabmann, 2008; Murphy, 2004). Hence, perceived procedural unfairness is expected to affect the level of tax non-compliance. Lastly, we verify the mediating effect of the level of tax non-compliance on the association between the perception of procedural fairness and likelihood of a tax re-audit.

This study adopts a survey method to measure the perception of procedural unfairness, level of tax noncompliance, and likelihood of a tax re-audit. The survey questionnaire is randomly distributed to 1,120 individuals via e-mail, mail, and direct visits from July 1 to August 31, 2018 . We collect 348 of the 1,120 distributed and finally use 342 completed questionnaires for the analysis, excluding six questionnaires with invalid responses. Using a final sample of 342 responses, we estimate cross-sectional regression models to test our hypotheses.

The results of our analysis are as follows. First, we find that the level of tax non-compliance determines the likelihood of a tax re-audit. Second, the level of tax noncompliance is influenced by the perception of procedural fairness. Lastly, the level of tax non-compliance mediates the association between the perception of procedural unfairness and likelihood of a tax re-audit. This finding indicates that the likelihood of a tax re-audit is not only determined by taxpayers' non-compliance level, but also by their perceived procedural unfairness. The findings of this study contribute to the tax compliance literature by shedding light on the mediating role of tax compliance unlike most studies, which have examined the determinants of tax compliance behavior in general. In addition, the findings imply that it is crucial to improve the procedural fairness of tax enforcement to reduce re-audits that may damage taxpayers' rights. This study, therefore, will be of keen interest to tax policymakers as well as the taxation profession and taxpayers.

The remainder of the paper proceeds as follows. Section 2 describes the relevant literature and proposes the hypotheses. Section 3 introduces the study's research method and model used to test the hypotheses. Section 4 presents the empirical results. Finally, Section 5 concludes.

\section{Literature Review and Hypotheses Development}

\subsection{Procedural Fairness and Tax Compliance}

There is a considerable amount of research on tax compliance. Jackson and Milliron (1986) and Richardson and Sawyer (2001) review prior tax compliance studies and propose key variables that may affect tax compliance behavior, such as the perception of the fairness of the tax system. The association between the perceived fairness of the tax system and tax compliance behavior is well documented. For instance, Song and Yabrough (1978) find that people with a higher belief in tax fairness tend to have a higher tax ethics score in the United States. Tan and Chin-Fatt (2000) show a positive association between the perception of the fairness of the tax system and tax compliance attitude, using a survey of students in New Zealand. Richardson (2005) also finds that tax compliance behavior is positively affected by the perception of fairness based on a survey of postgraduate students in Australia and Hong Kong. McGee, Nickerson, Pleshko and Broihahn (2012) survey approximately 1,100 individuals across six countries, finding that tax fairness underlies the ethics of tax evasion. More recently, Faizal and Palil (2015) suggest that the perception of the fairness of the tax system could increase tax compliance based on a survey of academics in Malaysia.

Some researchers focus on procedural fairness as a key variable for predicting tax compliance behavior. In the tax context, procedural fairness refers to the fair treatment of taxpayers by the tax authority and fair decision-making during taxation procedures (Murphy, 2004; Murphy, 2009; Van Dijke \& Verboon, 2010). From the psychological perspective, Frey (2003) asserts that the tax authority's respectful treatment and transparent procedure can reduce tax evasion because the way tax officials treat taxpayers affects the latter's tax morale and willingness to pay taxes. Hartner, Rechberger, Kirchler and Schabmann (2008) empirically examine the relationship between procedural fairness and tax compliance using a sample of 2,040 Australian taxpayers. They find that taxpayers are less compliant when they feel treated unfairly and disrespectfully by the tax authority. Similarly, Murphy and Tyler (2008) show that perceived procedural justice is positively related to tax compliance behavior using longitudinal survey data. They further suggest that emotions mediate the effect of procedural justice on tax compliance. Faizal and Palil (2015) also find that procedural fairness has a positive impact on tax compliance in Malaysia. Stalans and Lind (1997) examine procedural fairness in the context of tax audits by interviewing taxpayers and their representatives about the quality of treatment by auditors during tax audits. Their findings show that taxpayers more 
negatively evaluate the procedural fairness of tax audits than their representatives.

\subsection{Tax Re-audits}

In the United States, a tax re-audit is strictly prohibited under the rules of double jeopardy. According to Internal Revenue Code 7605 (b), "no taxpayer shall be subjected to unnecessary examination, and only one inspection of a taxpayer's books of account shall be made for each taxable year unless the taxpayer requests otherwise or unless the secretary, after investigation, notifies the taxpayer in writing that an additional inspection is necessary." Section 5 of Rev. Proc. 2005-32 states that a second inspection is not permitted unless "(1) there is evidence of fraud, collusion, concealment, or misrepresentation of material fact; (2) the disclosed case involves a clearly-defined, substantial error based on an established Service position existing at the time of the examination; or (3) other circumstances exist indicating that a failure to reopen the case would be serious administrative omission."

Likewise in Korea, tax officials are prohibited from investigating the same tax affairs within the same taxable period except for cases described in the Basic Act on National Taxes (Article 81-4) and the Enforcement Decree of Basic Act for National Taxes 63-2. According to Article 81-4 of the Basic Act on National Taxes, re-audits are limited to cases where clear evidence confirms a suspicion of tax evasion, where investigation of the counterpart of a transaction is necessary, where mistakes relating to two or more business years exist, or where a taxpayer provides money to a tax official in connection with his or her duties. The Enforcement Decree of Basic Act for National Taxes 63-2 additionally defines cases in which re-audits can be conducted, such as a general investigation undertaken against a person suspected of disturbing the economic order, an investigation for handling all kinds of assessment data, and an investigation to determine a tax refund.

Compared with the United States, the scope of exceptional cases of re-audits is more broadly described in Korea and thus, can be more arbitrarily interpreted by tax officials, which leads to a considerable number of legal disputes over re-audits. Indeed, Kim (2016) finds that current tax provisions on the requirements/procedures of re-audits are unclear and that re-audits are misused to compensate for a shortage of tax revenue, which eventually results in the infringement of the freedom and property rights of taxpayers. Further, Kim, Hur and Park (2017) analyze the 125 legal disputes over re-audits in 2006-2017, suggesting that taxpayers and tax authorities have different views of tax audits. They also find that the tax authority and court see the scope of exceptional re-audit cases more broadly than do taxpayers.

\subsection{Hypotheses Development}

In Korea, the increase in tax re-audits has become a critical issue in the context of the violation of taxpayer's property rights, leading to the above-mentioned increase in legal disputes between taxpayers and the tax authority. We first investigate the relationship between the possibility of tax non-compliance and likelihood of a tax re-audit. As mentioned previously, Korean tax laws specify exceptional cases that enable a re-audit. The Basic Act on National Taxes (Article 81-4) and the Enforcement Decree of Basic Act for National Taxes 63-2 define the exceptional cases in which tax officials can re-examine the same tax affairs within the same taxable period. Nevertheless, we assume that the likelihood of a tax re-audit in Korea is relatively high, as the tax authority tends to conduct re-audits to detect taxpayers' non-compliance behaviors by interpreting the scope of exceptional cases of re-audits broadly. Thus, we posit that the tax authority is more likely to conduct a reaudit when taxpayers tend to be less compliant with tax laws, even though it is not legitimate for it to conduct a re-audit without the strict application of the scope of exceptional re-audit cases. To investigate whether the level of tax noncompliance influences the likelihood of a tax re-audit, we formulate our first hypothesis as follows:

Hypothesis 1: The level of tax non-compliance influences the likelihood of a tax re-audit.

Next, we discuss tax enforcement procedures that may influence taxpayers' compliance behavior. Perceived procedural injustice causes the disobedience of laws by decreasing the legitimacy of the authority (Tyler, 1990). Applying this theory, the tax compliance literature provides empirical findings that tax enforcement procedures that taxpayers view as unfair increase their non-compliance (Frey, 2003; Hartner, Rechberger, Kirchler, \& Schabmann, 2008; Murphy \& Tyler, 2008; Van Dijke \& Verboon, 2010). In line with the theory and findings of prior studies, we thus posit that the level of tax non-compliance is affected by the perception of procedural unfairness. Specifically, we consider two aspects of procedural unfairness: operational inconsistency and regulatory lack of clarity. For example, a failure by the tax authority to consistently enforce tax laws in carrying out an audit or re-audit would increase perceived unfairness related to operational inconsistency and may lower taxpayers' compliance. In addition, if tax enforcement is not carried out based on clear regulations and laws, it would increase perceived unfairness related to regulatory lack of clarity and thus lead to the same consequence for tax compliance. To sum up, the extent to which taxpayers perceive procedural 
unfairness is expected to influence the level of tax noncompliance. This prediction is formally stated in our second hypothesis below:

Hypothesis 2: The perception of procedural unfairness influences the level of tax non-compliance.

Lastly, we examine the associations among the perception of procedural unfairness, tax non-compliance, and the likelihood of a tax re-audit. As discussed earlier, perceived procedural injustice enhances the level of noncompliance, which in turn raises the likelihood of a tax reaudit. Accordingly, we posit that the perception of procedural unfairness is a fundamental determinant of the likelihood of a tax re-audit, as non-compliance mediates the relation between the perception of procedural tax unfairness and such a likelihood. Our last hypothesis is therefore formulated as follows:

Hypothesis 3: The level of tax non-compliance mediates the relation between the perception of procedural unfairness and likelihood of a tax re-audit.

\section{Research Methods}

\subsection{Data Collection}

The researcher-administered questionnaire survey is used for data collection. A total of 1,120 questionnaires are randomly distributed to individuals with tax-related knowledge and experience between July 1 and August 31, 2018 through e-mail, mail, and direct visits. We collect 348 responses and remove six incomplete responses, resulting in a final sample of 342 questionnaires for the analysis.

The questionnaire comprises four parts. Section A consists of questions about respondents' perception of procedural tax unfairness related to operational inconsistency and regulatory lack of clarity. Sections B and C consist of questions on respondents' attitudes toward tax non-compliance and the likelihood of a tax re-audit, respectively. Respondents are requested to indicate their agreement with each question using a seven-point Likert scale. Section D comprises a series of questions on their demographic characteristics such as gender, age, length of work experience, occupation, and types of employment.

\subsection{Model Specification}

We begin our analysis by estimating Model 1 to investigate whether the level of tax non-compliance influences the likelihood of a tax re-audit. The main variables of interest, REAUDIT and NONCOMPLIANCE, stand for the likelihood of a tax re-audit and level of tax non-compliance, respectively. As stated in Hypothesis 1, if the tax authority is more likely to conduct a re-audit when taxpayers tend to be less compliant with laws, the coefficient $\beta_{1}$ would have a positive sign. To control for the effect of other factors, we add the respondent's gender (GENDER), age (AGE), length of work experience (EXP), types of employment (EMPLOY), and occupation (OCCUPATION) into Model 1:

REAUDIT $=\beta_{0}+\beta_{1}$ NONCOMPLIANCE $+\beta_{2}$ GENDER $+\beta_{3} A G E+\beta_{4} E X P+\beta_{5}$ EMPLOY $+\beta_{6}$ OCCUPATION $+\varepsilon$ (Model 1)

Next, we examine whether the level of tax non-compliance is affected by the perception of procedural unfairness by estimating Model 2. The explanatory variables, UNFAIR1 and UNFAIR2, represent the two aspects of procedural unfairness of operational inconsistency and regulatory lack of clarity, respectively. If the perceived unfairness related to operational inconsistency or regulatory lack of clarity increases the level of tax non-compliance, the coefficients $\beta_{1}$ and $\beta_{2}$ are expected to have a positive sign, respectively:

NONCOMPLIANCE $=\beta_{0}+\beta_{1}$ UNFAIR $1+\beta_{2}$ UNFAIR 2 $+\beta_{3}$ GENDER $+\beta_{4} A G E+\beta_{5} E X P+\beta_{6} E M P L O Y+\beta_{7}$ $O C C U P A T I O N+\varepsilon($ Model 2$)$

Lastly, we conduct the mediation analysis suggested by Baron and Kenny (1986) to test Hypothesis 3. We construct a three-stage regression to investigate whether NONCOMPLIANCE mediates the relationship between UNFAIR1 (or UNFAIR2) and REAUDIT. A mediation effect would exist if the following three conditions hold: (1) the coefficient of UNFAIR1 (or UNFAIR2) is significant in the first stage, (2) the coefficient of UNFAIR1 (or UNFAIR2) is significant in the second stage, and (3) the coefficient of UNFAIR1 (or UNFAIR2) in the third stage is not significant or smaller than that in the first stage. If the coefficient of UNFAIR1 (or UNFAIR2) in the third stage is insignificant, it implies that NONCOMPLIANCE fully mediates the relationship between UNFAIR1 (or UNFAIR2) and REAUDIT. Meanwhile, a significant but smaller coefficient of UNFAIR1 (or UNFAIR2) in third stage indicates the partial mediating effect of NONCOMPLIANCE on the relation between UNFAIR1 (or UNFAIR2) and REAUDIT.

REAUDIT $=\beta_{0}+\beta_{1}$ UNFAIR $1+\beta_{2}$ UNFAIR $2+\beta_{3}$ GENDER $+\beta_{4} A G E+\beta_{5} E X P+\beta_{6} E M P L O Y+\beta_{7}$ OCCUPATION $+\varepsilon$ (first stage: Model 3-1) 
NONCOMPLIANCE $=\beta_{0}+\beta_{1}$ UNFAIR1 $+\beta_{2}$ UNFAIR 2 $+\beta_{3}$ GENDER $+\beta_{4} A G E+\beta_{5}$ EXP $+\beta_{6}$ EMPLOY $+\beta_{7}$ OCCUPATION $+\varepsilon$ (second stage: Model 3-2)

REAUDIT $=\beta_{0}+\beta_{1}$ UNFAIR1 $+\beta_{2}$ UNFAIR $2+\beta_{3}$ NONCOMPLIANCE $+\beta_{4} G E N D E R+\beta_{5} A G E+\beta_{6} E X P+\beta_{7}$ EMPLOY $+\beta_{8}$ OCCUPATION $+\varepsilon$ (third stage: Model 3-3)

\section{Empirical Results}

\subsection{Descriptive Statistics and Factor Analysis}

Table 1 provides the demographic background of respondents in this study. The majority are men (74\%). As for age, the highest response rate comes from respondents in the $40-49$ age bracket (39.5\%) followed by the 50-59 age bracket $(24.6 \%)$. With respect to work experience, $39.2 \%$ of the sample have 10-19 years of work experience followed by the group with nine years or less (37.4\%). The majority of respondents belong to companies or institutions (81\%) and the rest are self-employed (19\%). The occupations of respondents are tax officials (56.1\%) and tax accountants (43.9\%) because the questionnaire is distributed to those with tax-related knowledge and experience.

Table 2 provides the descriptive statistics of the variables used in this study, namely procedural unfairness, tax noncompliance, and the likelihood of a tax re-audit. Concerning respondents' views on procedural unfairness, the mean score for UNFAIR2 is higher than that for UNFAIR1. This finding indicates that the level of perceived unfairness related to regulatory lack of clarity is higher than that related to operational inconsistency. The mean scores for NONCOMPLIANCE and REAUDIT are mostly above 4 , suggesting that respondents assess the level of tax noncompliance and likelihood of a tax re-audit as slightly high.

Table 3 presents the results of the factor analysis conducted using a rotated component matrix supported the three dimensions of tax attitudinal aspects: the perception of procedural unfairness, tax non-compliance, and the likelihood of a tax re-audit. The Cronbach's alpha value of between 0.787 and 0.823 indicates that the measurements employed in this study are reliable and consistent. The Kaiser-Mayer-Olkin technique produces the result of 0.891 (which is above the threshold limit of 0.6), suggesting that the current sampling is favorable to applying factor analysis (Kiser \& Rice, 1974). Finally, Bartlett's test of sphericity is highly significant $(p=0.00)$, supporting the validity of the dataset (Lee, 2017).

\subsection{Correlation Analysis}

Table 4 presents the Pearson correlations for the variables used in the tests. REAUDIT is positively correlated with NONCOMPLIANCE as expected. NONCOMPLIANCE has a significantly positive correlation with UNFAIR1 and UNFAIR2, suggesting that the level of tax non-compliance increases as the perceived unfairness related to operational inconsistency or regulatory lack of clarity increases. REAUDIT has a significantly positive correlation with UNFAIR1 and UNFAIR2. As for the control variables,

Table 1: Summary of the Demographic Data $(\mathrm{N}=342)$

\begin{tabular}{|l|l|c|c|c|}
\hline \multicolumn{2}{|c|}{ Variable } & Frequency & Percentage & $\begin{array}{c}\text { Cumulative } \\
\text { Percentage }\end{array}$ \\
\hline \multirow{4}{*}{ GENDER } & Male & 253 & 74 & 74 \\
\cline { 2 - 5 } & Female & 89 & 26 & 100 \\
\hline \multirow{5}{*}{ AGE } & Under 40 & 81 & 23.6 & 23.6 \\
\cline { 2 - 5 } & $40-49$ & 135 & 39.5 & 63.2 \\
\cline { 2 - 5 } & $50-59$ & 84 & 24.6 & 87.7 \\
\cline { 2 - 5 } & 60 or over & 42 & 12.3 & 100 \\
\hline \multirow{3}{*}{ EXPERIENCE } & Nine years or less & 128 & 37.4 & 37.4 \\
\cline { 2 - 5 } & $10-19$ years & 134 & 39.2 & 76.6 \\
\cline { 2 - 5 } & 20 years or over & 80 & 23.4 & 100 \\
\hline \multirow{3}{*}{ EMPLOY } & Employed by companies/ & 277 & 81 & 81 \\
\hline \multirow{2}{*}{ OCCUPATION } & institutions & 65 & 19 & 100 \\
\cline { 2 - 5 } & Self-employed & 150 & 43.9 & 13.9 \\
\cline { 2 - 5 } & Tax accountant & 192 & 56.1 & 100 \\
\cline { 2 - 5 } & Tax official & & & 2 \\
\hline
\end{tabular}


Table 2: Descriptive Statistics of the Variables $(\mathrm{N}=342)$

\begin{tabular}{|c|c|c|c|}
\hline Variable & Questionnaire Item & Mean & SD \\
\hline \multirow{3}{*}{ UNFAIR1 } & $\begin{array}{l}\text { Q1. The tax authority tends to conduct audits to achieve other economic } \\
\text { purposes such as curbing real estate speculation. }\end{array}$ & 4.55 & 1.59 \\
\hline & $\begin{array}{l}\text { Q2. The tax authority tends to conduct audits to achieve other political } \\
\text { purposes such as controlling the media. }\end{array}$ & 3.78 & 1.70 \\
\hline & $\begin{array}{l}\text { Q3. The tax authority tends to re-examine the same tax affairs by } \\
\text { excessively broadening the parameters of a re-audit. }\end{array}$ & 3.92 & 1.64 \\
\hline \multirow{3}{*}{ UNFAIR2 } & $\begin{array}{l}\text { Q4. The regulations pertaining to notifying taxpayers of a re-audit and the } \\
\text { reasons thereof are unclear. }\end{array}$ & 4.08 & 1.90 \\
\hline & $\begin{array}{l}\text { Q5. The regulations that prevent the abuse of re-audits or possible means } \\
\text { of defense by taxpayers against re-audits are unclear. }\end{array}$ & 4.35 & 1.81 \\
\hline & $\begin{array}{l}\text { Q6. The regulations that allow the tax authority to conduct a re-audit are } \\
\text { unclear. }\end{array}$ & 4.71 & 1.71 \\
\hline \multirow{6}{*}{ NONCOMPLIANCE } & $\begin{array}{l}\text { Q7. Taxpayers would not comply with tax laws if their tax burden is } \\
\text { increased by the policy of the government to compensate for a shortage } \\
\text { in tax revenue. }\end{array}$ & 4.22 & 1.50 \\
\hline & $\begin{array}{l}\text { Q8. Taxpayers would not comply with tax laws if tax laws become too } \\
\text { complicated with economic development. }\end{array}$ & 4.65 & 1.45 \\
\hline & $\begin{array}{l}\text { Q9. Taxpayers would not comply with tax laws if they have a low } \\
\text { capability of solving tax issues. }\end{array}$ & 4.16 & 1.50 \\
\hline & $\begin{array}{l}\text { Q10. Taxpayers would not comply with tax laws if their age is young, their } \\
\text { work experience is short, or their business size is small. }\end{array}$ & 3.80 & 1.51 \\
\hline & $\begin{array}{l}\text { Q11. Taxpayers would not comply with tax laws if the tax authority } \\
\text { arbitrarily operates the tax system. }\end{array}$ & 4.08 & 1.50 \\
\hline & $\begin{array}{l}\text { Q12. Taxpayers would not comply with tax laws if there is a lack of } \\
\text { regulations to prevent unnecessary re-audits. }\end{array}$ & 4.04 & 1.51 \\
\hline \multirow{6}{*}{ REAUDIT } & $\begin{array}{l}\text { Q13. The tax authority is likely to conduct a re-audit if it needs more tax } \\
\text { revenue for increased government spending. }\end{array}$ & 4.25 & 1.73 \\
\hline & $\begin{array}{l}\text { Q14. The tax authority is likely to conduct a re-audit if tax laws become } \\
\text { complicated to prevent tax evasion amid complex economic structures. }\end{array}$ & 5.12 & 1.37 \\
\hline & $\begin{array}{l}\text { Q15. The tax authority is likely to conduct a re-audit if taxpayers have less } \\
\text { capacity to solve tax issues. }\end{array}$ & 4.37 & 1.50 \\
\hline & $\begin{array}{l}\text { Q16. The tax authority is likely to conduct a re-audit if taxpayers are } \\
\text { young, work experience is short, or business size is small. }\end{array}$ & 4.10 & 1.48 \\
\hline & $\begin{array}{l}\text { Q17. The tax authority is likely to conduct a re-audit if the tax system is } \\
\text { arbitrarily operated. }\end{array}$ & 4.32 & 1.55 \\
\hline & $\begin{array}{l}\text { Q18. The tax authority is likely to conduct a re-audit if there is a lack of } \\
\text { regulations to prevent unnecessary re-audits. }\end{array}$ & 4.30 & 1.56 \\
\hline
\end{tabular}

GENDER and OCCUPATION are positively correlated with NONCOMPLIANCE, while EMPLOY is negatively correlated. GENDER, AGE3, and OCCUPATION are positively correlated with REAUDIT, while AGE1 and EMPLOY are negatively correlated.

\subsection{Regression Analysis}

Table 5 presents the results of estimating Model 1 to investigate whether the level of tax non-compliance influences the likelihood of a tax re-audit. We find that the 
Table 3: Factor Analysis

\begin{tabular}{|c|c|c|c|c|}
\hline \multicolumn{5}{|c|}{ Panel A. Procedural Unfairness } \\
\hline Variable & Questionnaire Item & Factor 1 & Factor 2 & Cronbach's $\alpha$ \\
\hline \multirow{3}{*}{ UNFAIR1 } & Q1 & 0.255 & 0.790 & \multirow{3}{*}{0.787} \\
\hline & Q2 & 0.135 & 0.861 & \\
\hline & Q3 & 0.392 & 0.732 & \\
\hline \multirow{3}{*}{ UNFAIR2 } & Q4 & 0.794 & 0.241 & \multirow{3}{*}{0.819} \\
\hline & Q5 & 0.891 & 0.176 & \\
\hline & Q6 & 0.773 & 0.316 & \\
\hline Eigenvalue & & 2.259 & 2.087 & \\
\hline \multicolumn{5}{|c|}{ Panel B. Tax Non-compliance } \\
\hline Variable & Questionnaire Item & & & Cronbach's a \\
\hline \multirow{6}{*}{ NONCOMPLIANCE } & Q7 & & & \multirow{6}{*}{0.817} \\
\hline & Q8 & & & \\
\hline & Q9 & & & \\
\hline & Q10 & & & \\
\hline & Q11 & & & \\
\hline & Q12 & & & \\
\hline \multicolumn{2}{|l|}{ Eigenvalue } & & & \\
\hline \multicolumn{5}{|c|}{ Panel C. Re-audit Likelihood } \\
\hline Variable & Questionnaire Item & & & Cronbach's $\alpha$ \\
\hline \multirow{6}{*}{ REAUDIT } & Q13 & & & \multirow{6}{*}{0.823} \\
\hline & Q14 & & & \\
\hline & Q15 & & & \\
\hline & Q16 & & & \\
\hline & Q17 & & & \\
\hline & Q18 & & & \\
\hline \multicolumn{2}{|l|}{ Eigenvalue } & & & \\
\hline
\end{tabular}

coefficient of NONCOMPLIANCE is positively significant at $p<0.01$, which indicates that the level of tax noncompliance is a significant determinant of the likelihood of a tax re-audit. The results support Hypothesis 1 that the level of tax non-compliance influences the likelihood of a tax reaudit.

Table 6 presents the results of estimating Model 2 to examine the relationship between the perception of procedural unfairness and level of tax non-compliance. The perception of procedural unfairness is measured by operational inconsistency (UNFAIR1) and regulatory lack of clarity (UNFAIR2). As shown in Table 6, the coefficients of UNFAIR1 and UNFAIR2 are both positively significant at $p<0.01$. The results indicate that the higher the perceived level of unfairness related to operational inconsistency or regulatory lack of clarity, the higher is the level of tax noncompliance. Thus, Hypothesis 2 is supported. We further find that operational inconsistency is more likely to influence the level of tax non-compliance than is regulatory lack of clarity based on a comparison of the coefficients of UNFAIR1 and UNFAIR2 (0.424>0.303).

Lastly, we conduct a three-stage regression analysis to investigate whether tax non-compliance mediates the link between the perception of procedural unfairness and likelihood of a tax re-audit. Table 7 summarizes the results of the analysis. In Panel A of Table 7, the coefficients of UNFAIR1 and UNFAIR2 in the firststage regression are both positive and significant at $p<0.01$, implying that the perception of procedural unfairness in relation to operational inconsistency and 
Table 4: Correlations of the Variables

\begin{tabular}{|c|c|c|c|c|c|c|c|c|c|c|c|c|}
\hline & \begin{tabular}{|c|} 
UN \\
FAIR1 \\
\end{tabular} & \begin{tabular}{|c} 
UN \\
FAIR2
\end{tabular} & $\begin{array}{c}\text { NON } \\
\text { COMPLIANCE }\end{array}$ & REAUDIT & GENDER & AGE1 & AGE2 & AGE3 & EXP1 & EXP2 & EMPLOY & OCCUPATION \\
\hline UNFAIR1 & 1.0000 & -0.0110 & $0.410^{* * *}$ & $0.434^{* * *}$ & 0.0840 & $-0.174^{* * *}$ & 0.0350 & 0.0140 & 0.0790 & 0.0430 & $0.238^{* * *}$ & $0.346^{* * *}$ \\
\hline UNFAIR2 & & 1.0000 & $0.314^{* * *}$ & $0.389^{* * *}$ & $0.179^{* * *}$ & -0.0320 & $-0.099^{*}$ & $0.145^{\star * *}$ & $0.118^{* *}$ & $-0.102^{*}$ & $0.093^{*}$ & $0.316^{\star * *}$ \\
\hline $\begin{array}{l}\text { NON } \\
\text { COMPLIANCE }\end{array}$ & & & 1.0000 & $0.597^{* * *}$ & $0.213^{* * *}$ & -0.0810 & -0.0510 & 0.0540 & 0.0680 & -0.0750 & $-0.114^{* *}$ & $0.235^{\star * \star}$ \\
\hline REAUDIT & & & & 1.0000 & $0.193^{* * *}$ & $-0.161^{* * *}$ & -0.0660 & $0.110^{\star *}$ & 0.0350 & -0.0610 & $-0.145^{\star * *}$ & $0.385^{* * *}$ \\
\hline GENDER & & & & & 1.0000 & $-0.285^{* * *}$ & $-0.116^{* *}$ & $0.275^{* * *}$ & $-0.152^{* * *}$ & 0.0320 & $-0.199^{* * *}$ & $0.317^{* * *}$ \\
\hline AGE1 & & & & & & 1.0000 & $-0.450^{* * *}$ & $-0.318^{* * *}$ & ${ }^{\star} 0.408^{* * *}$ & $-0.137^{* *}$ & $0.145^{\star \star *}$ & $-0.340^{* * *}$ \\
\hline AGE2 & & & & & & & 1.0000 & $-0.461^{\star \star \star *}$ & $\star-0.180^{* \star *}$ & $0.246^{\star * \star}$ & $0.143^{*}$ & $-0.232^{\star \star \star}$ \\
\hline AGE3 & & & & & & & & 1.0000 & $-0.147^{* \star *}$ & $-0.124^{* *}$ & -0.0600 & $0.276^{\star \star *}$ \\
\hline EXP1 & & & & & & & & & 1.0000 & $-0.621^{\star * *}$ & -0.0490 & 0.0710 \\
\hline EXP2 & & & & & & & & & & 1.0000 & 0.0330 & -0.0330 \\
\hline EMPLOY & & & & & & & & & & & 1.0000 & $-0.546^{\star * *}$ \\
\hline OCCUPATION & & & & & & & & & & & & 1.0000 \\
\hline
\end{tabular}

Notes: ${ }^{*},{ }^{* *}$, and ${ }^{* * *}$ indicate significance at the $10 \%, 5 \%$, and $1 \%$ levels, respectively based on two-tailed tests. The variables are defined as follows:

UNFAIR1=perception of procedural unfairness in relation to operational inconsistency; UNFAIR2=perception of procedural unfairness in relation to regulatory lack of clarity; NONCOMPLIANCE=level of tax non-compliance; REAUDIT=likelihood of a tax re-audit; GENDER=1 if a respondent's gender is male, and 0 otherwise; AGE1=1 if a respondent's age is under 40 , and 0 otherwise; AGE2=1 if a respondent's age is $40-49$, and 0 otherwise; AGE3=1 if a respondent's age is $50-59$, and 0 otherwise; EXP1=1 if a respondent's work experience is less 10 years, and 0 otherwise; EXP2 $=1$ if a respondent's work experience is $10-19$ years, and 0 otherwise; EMPLOY $=1$ if a respondent belongs to companies or institutions, and 0 if a respondent is self-employed; OCCUPATION=1 if a respondent's occupation is a tax accountant, and 0 if it is a tax official

Table 5: Effect of Tax Non-compliance on the Likelihood of a Tax Re-audit

\begin{tabular}{|l|c|c|c|c|}
\hline \multirow{2}{*}{ Variable } & \multicolumn{4}{c|}{ REAUDIT } \\
\cline { 2 - 5 } & Coef. & t-stat & p-value & VIF \\
\hline Intercept & -0.369 & -1.72 & 0.086 & 1.095 \\
\hline NONCOMPLIANCE & 0.537 & $12.261^{* * *}$ & 0.000 & 1.251 \\
\hline GENDER & -0.015 & -0.14 & 0.887 & 3.936 \\
\hline AGE1 & 0.000 & 0.00 & 0.998 & 3.593 \\
\hline AGE2 & 0.051 & 0.32 & 0.747 & 2.423 \\
\hline AGE3 & -0.013 & -0.09 & 0.931 & 2.368 \\
\hline EXP1 & -0.103 & -0.80 & 0.427 & 1.925 \\
\hline EXP2 & -0.094 & -0.81 & 0.417 & 1.467 \\
\hline EMPLOY & 0.206 & 1.64 & 0.102 & 2.263 \\
\hline OCCUPATION & 0.618 & $5.023^{* * *}$ & 0.000 & \\
\hline adj R2 & \multicolumn{4}{|c|}{0.41} \\
\hline F & \multicolumn{4}{|c|}{$27.211^{* * *}$} \\
\hline
\end{tabular}

Notes: The variables are defined as in Table 3. ${ }^{* *}$ indicates significance at the $1 \%$ level based on two-tailed tests. VIF means variance inflation factor.

regulatory lack of clarity influences the likelihood of a tax re-audit. Thus, Hypothesis 3-1 is supported. Panel B of Table 7 shows that the coefficients of UNFAIR1 and UNFAIR2 in the second-stage regression are both significantly positive at $p<0.01$, concurring with the results in Table 6. As shown in Panel $\mathrm{C}$ of Table 7, the 
Table 6: Effect of Perceived Procedural Unfairness on the Level of Tax Non-compliance

\begin{tabular}{|l|c|c|c|c|}
\hline \multirow{2}{*}{ Variable } & \multicolumn{4}{|c|}{ NONCOMPLIANCE } \\
\cline { 2 - 5 } & Coef. & t-stat & p-value & VIF \\
\hline Intercept & -0.065 & -0.27 & 0.791 & \\
\hline UNFAIR1 & 0.424 & $8.539^{* * *}$ & 0.000 & 1.209 \\
\hline UNFAIR2 & 0.303 & $6.141^{* * *}$ & 0.000 & 1.199 \\
\hline GENDER & 0.319 & $2.803^{* * *}$ & 0.005 & 1.236 \\
\hline AGE1 & -0.018 & -0.08 & 0.934 & 4.045 \\
\hline AGE2 & -0.106 & -0.60 & 0.546 & 3.660 \\
\hline AGE3 & -0.175 & -1.07 & 0.286 & 2.466 \\
\hline EXP1 & -0.123 & -0.86 & 0.393 & 2.421 \\
\hline EXP2 & -0.203 & -1.58 & 0.115 & 1.953 \\
\hline EMPLOY & 0.083 & 0.60 & 0.552 & 1.482 \\
\hline OCCUPATION & -0.066 & -0.46 & 0.646 & 2.550 \\
\hline adj R2 & \multicolumn{4}{|c|}{0.276} \\
\hline F & \multicolumn{4}{|c|}{$13.954^{* * *}$} \\
\hline
\end{tabular}

Notes: The variables are defined as in Table 3. ${ }^{* * *}$ indicates significance at the $1 \%$ level based on two-tailed tests.

VIF means variance inflation factor.

coefficients of UNFAIR1 and UNFAIR2 in the thirdstage regression are both significant but smaller than those in the first-stage regression. This finding suggests that the effect of UNFAIR1 and UNFAIR2 on REAUDIT becomes weak when the mediator, NONCOMPLIANCE, is introduced into the model. Therefore, Hypothesis 3-2 is well supported, as the findings indicate that tax noncompliance partially mediates the association between the perception of procedural unfairness and likelihood of a tax re-audit.

\section{Conclusions}

This study examines the determinants of the likelihood of a tax re-audit and mediating effect of tax non-compliance. Based on a survey conducted in Korea with 342 responses, we find that the level of tax noncompliance significantly affects the likelihood of a tax reaudit. This finding suggests that the increase in re-audits in Korea can be explained by the tendency of the tax authority to broadly conduct re-audits to detect taxpayers' non-compliance behavior, rather than strictly applying the scope of exceptional re-audit cases as stipulated in the relevant laws. We also find that the level of tax noncompliance is influenced by the perception of procedural unfairness, measured by operational inconsistency and regulatory lack of clarity. Lastly, our findings show that the level of tax non-compliance mediates the relationship between the perception of procedural unfairness and likelihood of a tax re-audit. This finding indicates that enhancing procedural fairness could fundamentally reduce unnecessary re-audits that infringe on the rights of taxpayers, as the likelihood of a tax re-audit is not solely determined by the level of tax non-compliance but also by perceived procedural fairness.

This study has the following limitations. First, we conduct our tests using survey data because of restricted access to data on re-audits from the tax authority. Second, the survey respondents in this study may not be representative of taxpayers, as they are limited to tax officials and tax accountants. Therefore, one should be cautious about generalizing the findings in this study. This study could be further developed by surveying a wide range of respondents such as tax experts. Nonetheless, this study contributes to the tax literature. It provides evidence of a linkage between the perception of procedural fairness and likelihood of a tax re-audit. Furthermore, the research uncovers the role of tax noncompliance as a mediator in the proposed relationship. The evidence presented in this study can help tax policymakers better implement suitable strategies to improve tax compliance and minimize the likelihood of a tax re-audit to protect taxpayers' rights. 
Table 7: Mediating Effect of Tax Non-compliance on the Relationship between the Perception of Procedural Unfairness and Likelihood of a Tax Re-audit

\begin{tabular}{|c|c|c|c|c|}
\hline \multicolumn{5}{|c|}{ Panel A. Results of Regression Model 3-1 (first stage) } \\
\hline \multirow{2}{*}{ Variable } & \multicolumn{4}{|c|}{ REAUDIT } \\
\hline & Coef. & t-stat & p-value & VIF \\
\hline Intercept & -0.146 & -0.64 & 0.523 & \\
\hline UNFAIR1 & 0.406 & $8.693^{* * *}$ & 0.000 & 1.209 \\
\hline UNFAIR2 & 0.344 & $7.412^{* * *}$ & 0.000 & 1.199 \\
\hline Control Variables & \multicolumn{4}{|c|}{ Included } \\
\hline adj R2 & \multicolumn{4}{|c|}{0.276} \\
\hline $\mathrm{F}$ & \multicolumn{4}{|c|}{$13.954^{* * *}$} \\
\hline \multicolumn{5}{|c|}{ Panel B. Results of Regression Model 3-2 (second stage) } \\
\hline \multirow{2}{*}{ Variable } & \multicolumn{4}{|c|}{ NONCOMPLIANCE } \\
\hline & Coef. & t-stat & p-value & VIF \\
\hline Intercept & -0.065 & -0.27 & 0.791 & \\
\hline UNFAIR1 & 0.424 & $8.539^{* * *}$ & 0.000 & 1.209 \\
\hline UNFAIR2 & 0.303 & $6.141^{* * *}$ & 0.000 & 1.199 \\
\hline Control Variables & \multicolumn{4}{|c|}{ Included } \\
\hline adj R2 & \multicolumn{4}{|c|}{0.364} \\
\hline $\mathrm{F}$ & \multicolumn{4}{|c|}{$20.376^{* * *}$} \\
\hline \multicolumn{5}{|c|}{ Panel C. Results of Regression Model 3-3 (third stage) } \\
\hline \multirow{2}{*}{ Variable } & \multicolumn{4}{|c|}{ REAUDIT } \\
\hline & Coef. & t-stat & p-value & VIF \\
\hline Intercept & -0.121 & -0.58 & 0.562 & \\
\hline UNFAIR1 & 0.240 & $5.097^{* * *}$ & 0.000 & 1.477 \\
\hline UNFAIR2 & 0.225 & $5.045^{\star * *}$ & 0.000 & 1.337 \\
\hline NONCOMPLIANCE & 0.393 & $8.327^{* * *}$ & 0.000 & 1.424 \\
\hline Control Variables & \multicolumn{4}{|c|}{ Included } \\
\hline adj R2 & \multicolumn{4}{|c|}{0.473} \\
\hline $\mathrm{F}$ & \multicolumn{4}{|c|}{$28.673^{* * *}$} \\
\hline
\end{tabular}

Notes: The variables are defined as in Table $3{ }^{* * *}$ indicates significance at the $1 \%$ level based on two-tailed tests.

VIF means variance inflation factor.

\section{References}

Baron, R. M., \& Kenny, D. A. (1986). The moderator-mediator variable distinction in social psychological research: Conceptual, strategic, and statistical considerations. Journal of personality and social psychology, 51(6), 1173.

Faizal, S. M., \& Palil, M. R. (2015). Study on fairness and individual tax compliance in Malaysia: Preliminary findings. International Journal of Business, Economics and Law, 8(1), 74-79.

Frey, B. S. (2003). Deterrence and tax morale in the European Union. European Review, 11(3), 385-406.
Hartner, M., Rechberger, S., Kirchler, E., \& Schabmann, A. (2008). Procedural fairness and tax compliance. Economic analysis and policy, 38(1), 137.

Jackson, B. R., \& Milliron, V. C. (1986). Tax compliance research: Findings, problems, and prospects. Journal of accounting literature, 5(1), 125-165.

Kaiser, H. F., \& Rice, J. (1974). Little jiffy, mark IV. Educational and psychological measurement, 34(1), 111-117.

Kim, N. (2016). Study on the legal issues of duplicate tax audit. Public Law Journal, 17(3), 205-233. [printed in Korean]. 
Kim, W. Y., Hur, W. \& Park. H. (2017). A Proposal for Improving the Limitation and Permission of Duplicate Tax Audits through Analyzing the Tax Disputes. Journal of Taxation and Accounting, 18(4), 147-171. [printed in Korean].

Lee, J. W. (2017). Critical factors affecting consumer acceptance of online health communication: an application of service quality models. Journal of Asian Finance, Economics and Business, 4(3), 85-94. http://dx.doi.org/10.13106/jafeb.2017.vol4.no3.85

Long, S., \& Swingen, J. (1991). Taxpayer Compliance: Setting New Agendas for Research. Law and Society Review, 25(3), 637-683.

McGee, R. W., Nickerson, I., Pleshko, L., \& Broihahn, M. (2012). The ethics of tax evasion: An investigation into demographic differences. Journal of Legal, Ethical and Regulatory Issues, 15(1), 105.

Murphy, K. (2004). The role of trust in nurturing compliance: A study of accused tax avoiders. Law and human behavior, 28(2), 187-209.

Murphy, K. (2009). Procedural justice and affect intensity: Understanding reactions to regulatory authorities. Social Justice Research, 22(1), 1-30.

Murphy, K., \& Tyler, T. (2008). Procedural justice and compliance behaviour: The mediating role of emotions. European journal of social psychology, 38(4), 652-668.

Nguyen, H. H. (2019). Impact of Direct Tax and Indirect Tax on Economic Growth in Vietnam. Journal of Asian Finance, Economics and Business, 6(4), 129-137. https://doi. org/10.13106/jafeb.2019.vol6.no4.129

Nguyen, T. T. D., Pham, T. M. L., Le, T. T., Truong, T. H. L., \& Tran, M. D. (2020). Determinants Influencing Tax Compliance: The Case of Vietnam. Journal of Asian Finance, Economics and Business, 7(2), 65-73. https://doi.org/10.13106/jafeb.2020. vol7.no2.65

Richardson, G. (2005). An Exploratory Cross-cultural Study of Tax Fairness Perceptions and Tax Compliance Behavior in Australia and Hong Kong. International Tax Journal, 31(1), 11-24.

Richardson, M., \& Sawyer, A. J. (2001). A Taxonomy of the Tax Compliance Literature: Further Findings Problems and Prospects. Australian Tax Forum, 16(2), 137.

Sapiei, N. S., Kasipillai, J., \& Eze, U. C. (2014). Determinants of tax compliance behaviour of corporate taxpayers in Malaysia. eJournal of Tax Research, 12, 383-409.

Slemrod, J., Blumenthal, M., \& Christian, C. (2001). Taxpayer response to an increased probability of audit: evidence from a controlled experiment in Minnesota. Journal of public economics, 79(3), 455-483.

Song, Y. D., \& Yarbrough, T. E. (1978). Tax Ethics and Taxpayer Attitudes: A Survey. Public Administration Review, 38(5), 442452.

Stalans, L., \& Lind, E. A. (1997). The meaning of procedural fairness: A comparison of taxpayers' and representatives' views of their tax audits. Social Justice Research, 10(3), 311-331.
Tan, L. M., \& Chin-Fatt, C. (2000). The impact of tax knowledge on the perceptions of tax fairness and attitudes towards compliance. Asian review of accounting, 8(1), 44-58.

Tyler, T. R. (1990). Why People Obey the Law: Procedural Justice, Legitimacy, and Compliance. New Haven: Yale University Press.

Van Dijke, M., \& Verboon, P. (2010). Trust in authorities as a boundary condition to procedural fairness effects on tax compliance. Journal of Economic Psychology, 31(1), 80-91.

\section{Appendixes}

Questionnaire: Kindly respond to the following statements to indicate your opinion on each of them. Please tick one box of the seven-point scale against each statement.

Section A: Procedural Unfairness

\begin{tabular}{|l|c|}
\hline Questionnaire item & $\begin{array}{c}\text { 1: Strongly disagree } \\
\text { 7: Strongly agree }\end{array}$ \\
\hline $\begin{array}{l}\text { The tax authority tends to conduct } \\
\text { audits to achieve other economic } \\
\text { purposes such as curbing real } \\
\text { estate speculation. }\end{array}$ & $1,2,3,4,5,6,7$ \\
\hline $\begin{array}{l}\text { The tax authority tends to conduct } \\
\text { audits to achieve other political } \\
\text { purposes such as controlling the } \\
\text { media. }\end{array}$ & $1,2,3,4,5,6,7$ \\
\hline $\begin{array}{l}\text { The tax authority tends to re- } \\
\text { examine the same tax affairs } \\
\text { by excessively broadening the } \\
\text { parameters of a re-audit. }\end{array}$ & $1,2,3,4,5,6,7$ \\
\hline $\begin{array}{l}\text { The regulations pertaining to } \\
\text { notifying taxpayers of a re-audit } \\
\text { and the reasons thereof are } \\
\text { unclear. }\end{array}$ & $1,2,3,4,5,6,7$ \\
\hline $\begin{array}{l}\text { The regulations that prevent the } \\
\text { abuse of re-audits or possible } \\
\text { means of defense by taxpayers } \\
\text { against re-audits are unclear. }\end{array}$ & $1,2,3,4,5,6,7$ \\
\hline $\begin{array}{l}\text { The regulations that allow the tax } \\
\text { authority to conduct re-audits are } \\
\text { unclear. }\end{array}$ & $1,2,3,4,5,6,7$ \\
\hline
\end{tabular}

Section A: Procedural Unfairness

\begin{tabular}{|l|c|}
\hline Questionnaire item & $\begin{array}{c}\text { 1: Strongly disagree } \\
\text { 7: Strongly agree }\end{array}$ \\
\hline $\begin{array}{l}\text { The tax authority tends to } \\
\text { conduct audits to achieve other } \\
\text { economic purposes such as } \\
\text { curbing real estate speculation. }\end{array}$ & $1,2,3,4,5,6,7$ \\
\hline
\end{tabular}




\begin{tabular}{|l|c|}
\hline Questionnaire item & $\begin{array}{c}\text { 1: Strongly disagree } \\
\text { 7: Strongly agree }\end{array}$ \\
\hline $\begin{array}{l}\text { The tax authority tends to } \\
\text { conduct audits to achieve other } \\
\text { political purposes such as } \\
\text { controlling the media. }\end{array}$ & $1,2,3,4,5,6,7$ \\
\hline $\begin{array}{l}\text { The tax authority tends to re- } \\
\text { examine the same tax affairs } \\
\text { by excessively broadening the } \\
\text { parameters of a re-audit. }\end{array}$ & $1,2,3,4,5,6,7$ \\
\hline $\begin{array}{l}\text { The regulations pertaining to } \\
\text { notifying taxpayers of a re-audit } \\
\text { and the reasons thereof are } \\
\text { unclear. }\end{array}$ & $1,2,3,4,5,6,7$ \\
\hline $\begin{array}{l}\text { The regulations that prevent the } \\
\text { abuse of re-audits or possible } \\
\text { means of defense by taxpayers } \\
\text { against re-audits are unclear. }\end{array}$ & $1,2,3,4,5,6,7$ \\
\hline $\begin{array}{l}\text { The regulations that allow the tax } \\
\text { authority to conduct re-audits are } \\
\text { unclear. }\end{array}$ & $1,2,3,4,5,6,7$ \\
\hline
\end{tabular}

Section B: Tax Non-compliance

\begin{tabular}{|l|c|}
\hline Questionnaire item & $\begin{array}{c}\text { 1: Strongly disagree } \\
\text { 7: Strongly agree }\end{array}$ \\
\hline $\begin{array}{l}\text { Taxpayers would not comply } \\
\text { with tax laws if their tax burden } \\
\text { is increased by the policy of the } \\
\text { government to compensate for a } \\
\text { shortage of tax revenue. }\end{array}$ & $1,2,3,4,5,6,7$ \\
\hline $\begin{array}{l}\text { Taxpayers would not comply } \\
\text { with tax laws if tax laws become } \\
\text { too complicated with economic } \\
\text { development. }\end{array}$ & $1,2,3,4,5,6,7$ \\
\hline $\begin{array}{l}\text { Taxpayers would not comply } \\
\text { with tax laws if they have low } \\
\text { capability of solving tax issues. }\end{array}$ & $1,2,3,4,5,6,7$ \\
\hline $\begin{array}{l}\text { Taxpayers would not comply with } \\
\text { tax laws if their age is young, their } \\
\text { work experience is short, or their } \\
\text { business size is small. }\end{array}$ & $1,2,3,4,5,6,7$ \\
\hline $\begin{array}{l}\text { Taxpayers would not comply } \\
\text { with tax laws if the tax authority } \\
\text { arbitrarily operates the tax } \\
\text { system. }\end{array}$ & $1,2,3,4,5,6,7$ \\
\hline $\begin{array}{l}\text { Taxpayers would not comply } \\
\text { with tax laws if there is a } \\
\text { lack of regulations to prevent } \\
\text { unnecessary re-audits. }\end{array}$ & $1,2,3,4,5,6,7$ \\
\hline
\end{tabular}

Section C: Likelihood of a Tax Re-audit

\begin{tabular}{|l|c|}
\hline Questionnaire item & $\begin{array}{c}\text { 1: Strongly disagree } \\
\text { 7: Strongly agree }\end{array}$ \\
\hline $\begin{array}{l}\text { The tax authority is likely to } \\
\text { conduct a re-audit if it needs } \\
\text { more tax revenue for increased } \\
\text { government spending. }\end{array}$ & $1,2,3,4,5,6,7$ \\
\hline $\begin{array}{l}\text { The tax authority is likely to } \\
\text { conduct a re-audit if tax laws } \\
\text { become complicated to prevent } \\
\text { tax evasion amid complex } \\
\text { economic structures. }\end{array}$ & $1,2,3,4,5,6,7$ \\
\hline $\begin{array}{l}\text { The tax authority is likely to } \\
\text { conduct a re-audit if taxpayers } \\
\text { have less capacity to solve tax } \\
\text { issues. }\end{array}$ & $1,2,3,4,5,6,7$ \\
\hline $\begin{array}{l}\text { The tax authority is likely to } \\
\text { conduct a re-audit if taxpayers are } \\
\text { young, work experience is short, } \\
\text { or business size is small. }\end{array}$ & $1,2,3,4,5,6,7$ \\
\hline $\begin{array}{l}\text { The tax authority is likely to } \\
\text { conduct a re-audit if the tax } \\
\text { system is arbitrarily operated. }\end{array}$ & $1,2,3,4,5,6,7$ \\
\hline $\begin{array}{l}\text { The tax authority is likely to } \\
\text { conduct a re-audit if there is a } \\
\text { lack of regulations to prevent } \\
\text { unnecessary re-audits. }\end{array}$ & $1,2,3,4,5,6,7$ \\
\hline
\end{tabular}

Section D: General Information (Kindly tick the most appropriate responses)

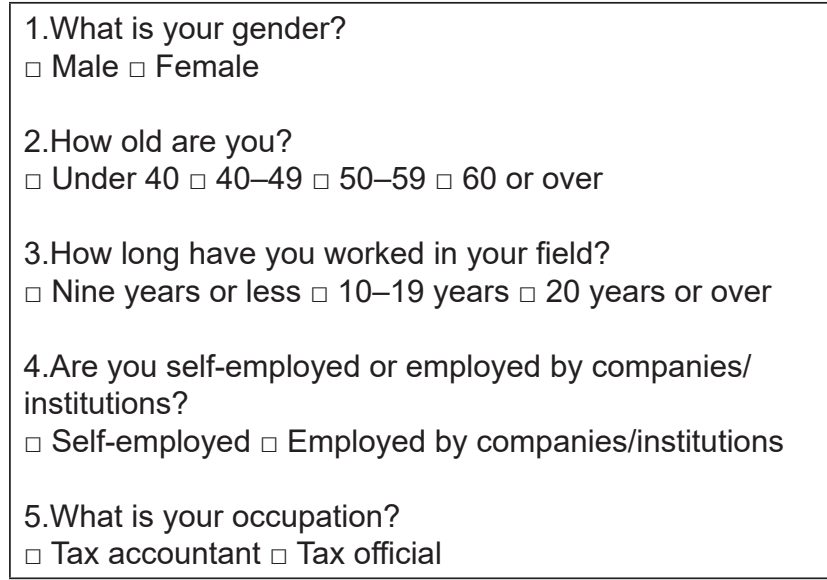

Thank you for taking the time to participate in this survey. The opinions in the questionnaire and any information identifying the respondents will not be disclosed. 